\title{
Use of geoprocessing to define malaria risk areas and evaluation of the vectorial importance of anopheline mosquitoes (Diptera: Culicidae) in Espírito Santo, Brazil
}

\author{
Viviane Coutinho Meneguzzi ${ }^{1 /+}$, Claudiney Biral dos Santos ${ }^{3}$, Israel de Souza Pinto², \\ Leandro Roberto Feitoza ${ }^{4}$, Hideko Nagatani Feitoza ${ }^{4}$, Aloísio Falqueto ${ }^{2}$
}

1Programa de Pós Graduação em Saúde Coletiva ²Unidade de Medicina Tropical, Universidade Federal do Espírito Santo, Av. Marechal Campos 1468, 29040-090 Vitória, ES, Brasil ${ }^{3}$ Núcleo de Entomologia, Secretaria de Saúde do Espírito Santo, Vitória, ES, Brasil ${ }^{4}$ GEOBASES, Unidade Central/IJSN, Vitória, ES, Brasil

In Brazil, introduced malaria occurs from the flat to the sloping hot areas, predominantly outside the Amazon Region, where endemic malaria has occurred in the past. This is a consequence of human migrations to other Brazilian states, including the state of Espirito Santo (ES). The objective of this study was to use geoprocessing to define the areas at risk of introduced malaria transmission and evaluate the vectorial importance of species of anophelines in ES. Anophelines were sampled from 1997-2005 in 297 rural localities identified or not identified as foci of malaria during the last 20 years. The geoclimatic variables temperature, relief and marine influence were obtained from a database of the ES Natural Units. The 14,663 anophelines captured belonged to 22 species. A significant association was found between the occurrence of malaria foci and the presence of hot, low-lying areas or gently undulating to undulating relief. The occurrence of the disease was associated with the presence of Anopheles darlingi and Anopheles aquasalis. Geoprocessing was determined to be a useful tool for defining areas at risk for malaria and vectors in ES.

Key words: malaria - Anopheles - geoclimatic variables - Espírito Santo - Brazil

Malaria is recognized globally as a grave public health problem. In 2006, there were an estimated 247 million malaria cases worldwide of which $86 \%$ occurred in the African region, 9\% in South-East Asia, $3 \%$ in Eastern Mediterranean Regions and $1 \%$ in the Americas (WHO 2008).

According to WHO (2008), an estimated $50 \%$ of the human population is exposed to the risk of contracting the disease in more than 100 countries, particularly in tropical and subtropical regions. There were an estimated 881,000 deaths worldwide in 2006 , of which $90 \%$ were in the African region and $85 \%$ in children under five years.

In Brazil, the number of cases reported in 2006 was estimated at 1.4 million, over half of the total for the Americas (WHO 2008). According to the Brazilian Ministry of Health (MS 2007), 99.5\% of the notified cases of malaria in Brazil occurred in the endemic region known as the Legal Amazon region and most of the remaining $0.5 \%$ represent exports from this region to the rest of the country. Outbreaks of malaria in the extraAmazonian regions of Brazil frequently occur in lowlying areas throughout the country, associated with the breeding areas of Anopheles spp. In recent years, large human migrations from the Amazonian Region to other Brazilian states have produced outbreaks of secondary cases derived from imported cases (introduced malaria),

+ Corresponding author: vmeneguzzi@gmail.com

Received 22 October 2008

Accepted 31 March 2009 such as those recorded recently in Ceará during 2002 and Piauí and Espírito Santo (ES) in 2004, 2005 and 2006 (Rey 2001, Forattini 2002, MS 2007).

Within the Southeastern Region of Brazil, ES is noteworthy as the state with the highest malaria potential due to its topographical and climatic characteristics, which favour breeding of the vectors (MS 2003, 2007). Timber extraction was an important economic activity in ES until the 1970s, when deforestation led to the migration of large numbers of families to the Amazon, particularly the states of Pará (PA) and Rondônia (RO). This led to the movement of people between malaria-endemic regions and $\mathrm{ES}$, where the descendants of the migrants still live (Marques 1986, IPEMA 2004).

The first studies on the anopheline fauna of ES were performed by Coutinho (1947), Andrade and Brandão (1957) and Ferreira (1964). These authors identified 21, 22 and 24 species of anophelines respectively, with Anopheles darlingi being recorded in all the surveys. These species represent almost half the anopheline fauna of Brazil, which includes 54 species (Deane 1986, Consoli \& Lourenço-de-Oliveira 1994, Neves et al. 2000, Neves 2003).

The distribution of insect vectors shows a close relationship with the geographical and climatic characteristics of each region (Forattini 2004). The geographical information system (GIS) is the geoprocessing technique most commonly used to describe events observed in a particular geographical space, such as the presence of vector species and environmental factors that influence their distribution (Margonari et al. 2006).

In Brazil, the use of geoprocessing to identify natural communities that tend to concentrate in ecosystems where the ecology is simultaneously favourable to vec- 
tors, hosts and micro-organisms has been used by various authors in studies of malaria in the Brazilian states of Roraima, RO, PA and Mato Grosso (Vasconcelos et al. 2006, Atanaka-Santos et al. 2007, Rosa-Freitas et al. 2007, Zeilhofer et al. 2007, Rodrigues et al. 2008). In ES, studies on the spatial distribution and geographic characteristics of diseases have been performed for visceral and tegumentary leishmaniases (Falqueto et al. 2001).

Two epidemiological patterns of the disease are recognized in this state: autochthonous malaria (malaria contracted locally) in the mountains, which is restricted to forested areas at elevations of approximately $800 \mathrm{~m}$ with a mean annual temperature of $17^{\circ} \mathrm{C}$ and lowland malaria in areas below $300 \mathrm{~m}$ with a mean annual temperature varying from $21-23^{\circ} \mathrm{C}$, which has been introduced by migrants from endemic areas, principally Amazonia (Feitoza et al. 2001, FUNASA 2004). Studies by Rezende et al. (2005) and Rodrigues (2005) suggest that Anopheles cruzii is the vector of the former and An. darlingi of the latter. However, little is known about the participation of other anopheline species in the transmission of the disease, not only in ES, but also in other regions of the country. In the present study, geoprocessing was used to define the areas at risk of malaria transmission and to evaluate the vectorial importance of anophelines in ES.

\section{MATERIALS AND METHODS}

Study area - ES is located in the Southeastern Region

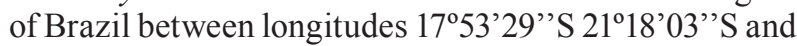
latitudes $39^{\circ} 41^{\prime} 18^{\prime \prime} \mathrm{W} 41^{\circ} 52^{\prime} 45^{\prime \prime} \mathrm{W}$. Its geographical area of $46,184 \mathrm{~km}^{2}$ represents only $0.58 \%$ of the national territory. It is divided into four mesoregions and 13 microregions, administered by 78 municipalities (Fig. 1).

Sampling - The present study was based on secondary data obtained from 297 rural localities, from all 78 municipalities of ES. Malaria foci were characterized from the records of autochthonous cases for the different localities included in the study, according to reports sent to the Brazilian National Health Service (FUNASA) and Secretaryship of Health of ES (SESA) from 1985-2005 (FUNASA 2004).

The malaria foci were established when the presence of the first autochthonous case of the disease was registered in the municipality. Thus, the imported case from an endemic region can transmit malaria to an introduced case and the latter can transmit to an autochthonous case, if the region was vulnerable to this broadcast, because of the presence of biogeographical conditions for the development of vector species of epidemiological importance (FUNASA 2001).

Characterization of the anopheline fauna was based on collections assembled by technicians of the Entomology's Nucleus of SESA/Federal University of Espírito Santo from 1997-2005, in all the municipalities of ES, whether they were malaria foci or not.

The disparity between the historical background of the collection of anopheline mosquitoes and malaria foci does not seem to influence the results presented because there were no significant changes in the environmental characteristics of ES in the last 20 years (IPEMA 2004).
Anophelines were collected by active searches in the peridomicile during the first four hours after sunset, using a Castro aspirator. Insects were captured in the surrounding dwellings, resting on external house walls and domestic animal shelters.

They were identified using a key for adults of Anopheles species of Brazil (Consoli \& Lourenço-deOliveira 1994).

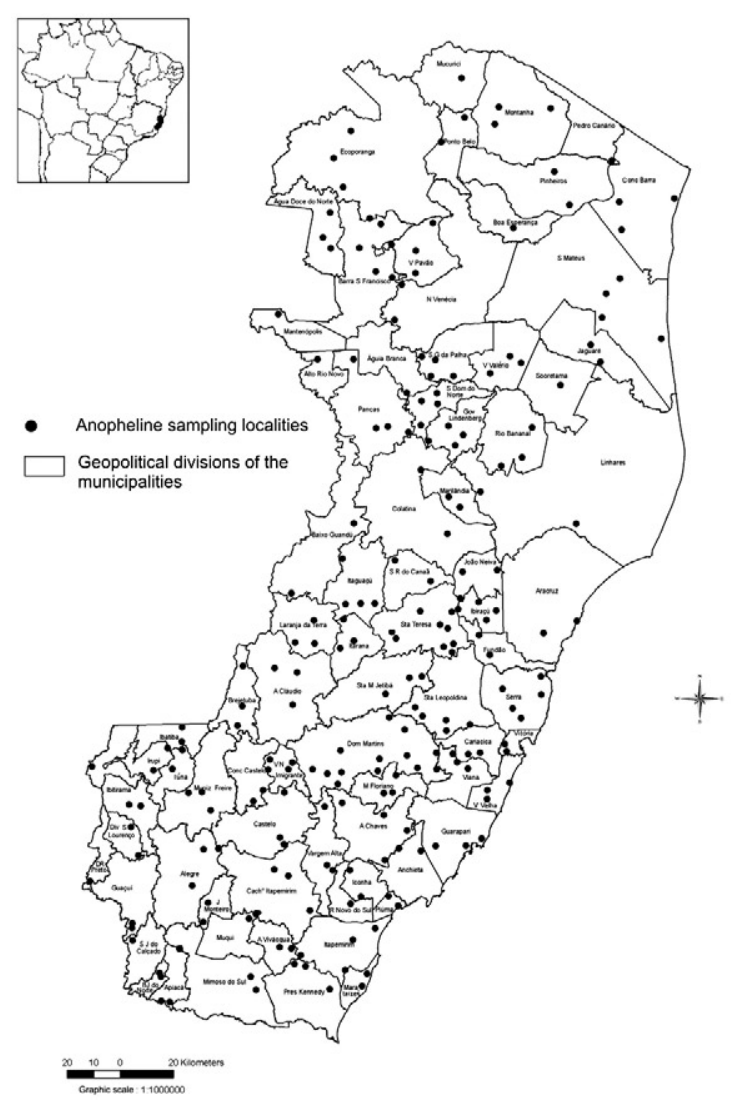

Fig. 1: geographical distribution of anopheline sampling localities in the state of Espírito Santo, Brazil.

TABLE I

State of Espírito Santo, Brazil, natural zones and area of coverage

Natural zones ${ }^{a}$

\begin{tabular}{lcr}
\hline Denomination & Acronym & $\begin{array}{r}\text { Area } \\
(\%)\end{array}$ \\
\hline Cold, sloping and rainy lands & FAC & 8,70 \\
Mild, sloping and rainy lands & AAC & 11,80 \\
Mild, sloping and rainy/dry lands & AACS & 6,90 \\
Hot, sloping and rainy lands & QAC & 4,10 \\
Hot, sloping and rainy/dry lands & QACS & 6,70 \\
Hot, sloping and and dry lands & QAS & 31,20 \\
Hot, low relief and rainy lands & QPC & 3,20 \\
Hot, low relief and rainy/dry lands & APCS & 11,20 \\
Hot, low relief and dry lands & QPS & 16,20
\end{tabular}

$a$ : data from SEAMA (2008). 
Ecological variables - Based on the Espirito Santo Ecosystems Atlas, nine natural zones occur in ES (Table I) (SEAMA 2008). Since water parameters were excluded from this study, seven zones were redefined. This redefinition was based on the association between the variables of temperature, relief and marine influence (Table IIA) and obtained from the Natural Units database at the zone and subzone level. These were processed using GISUNES, a system that catalogues information for the ecological characterization of regions of the state (Feitoza et al. 2001, Feitoza 2006) (Table IIB).

Statistical analysis - Statistical analysis was performed using software (SPSS version 10) and significance was defined as $p<0.05$. In the first stage, univariate analysis was carried out by means of the chi-square test to determine whether there were associations between the geoclimatic characteristics of the 297 localities studied and the presence or absence of foci of the disease, with a view to identifying the areas at risk for malaria transmission in ES. The second stage of the analysis associated the presence or absence of each species of anopheline with areas defined as being propitious for the occurrence of malaria by the chi-square test. The anopheline species that showed significant relationships with the areas where malaria occurred were then submitted to multivariate analysis by means of binary logistic regression to confirm this association. Maps were obtained using GEOBASES and GISUNES, operational in GIS, that served as a basis for the study of associations between the different variables (Feitoza et al. 2001).

TABLE II

Applied criteria for temperature and relief (A) and definition of zones resulting from the environmental variables (B) in the state of Espirito Santo, Brazil

A: applied criteria for temperature and relief used to classify natural units at zone level, excluding water parameters

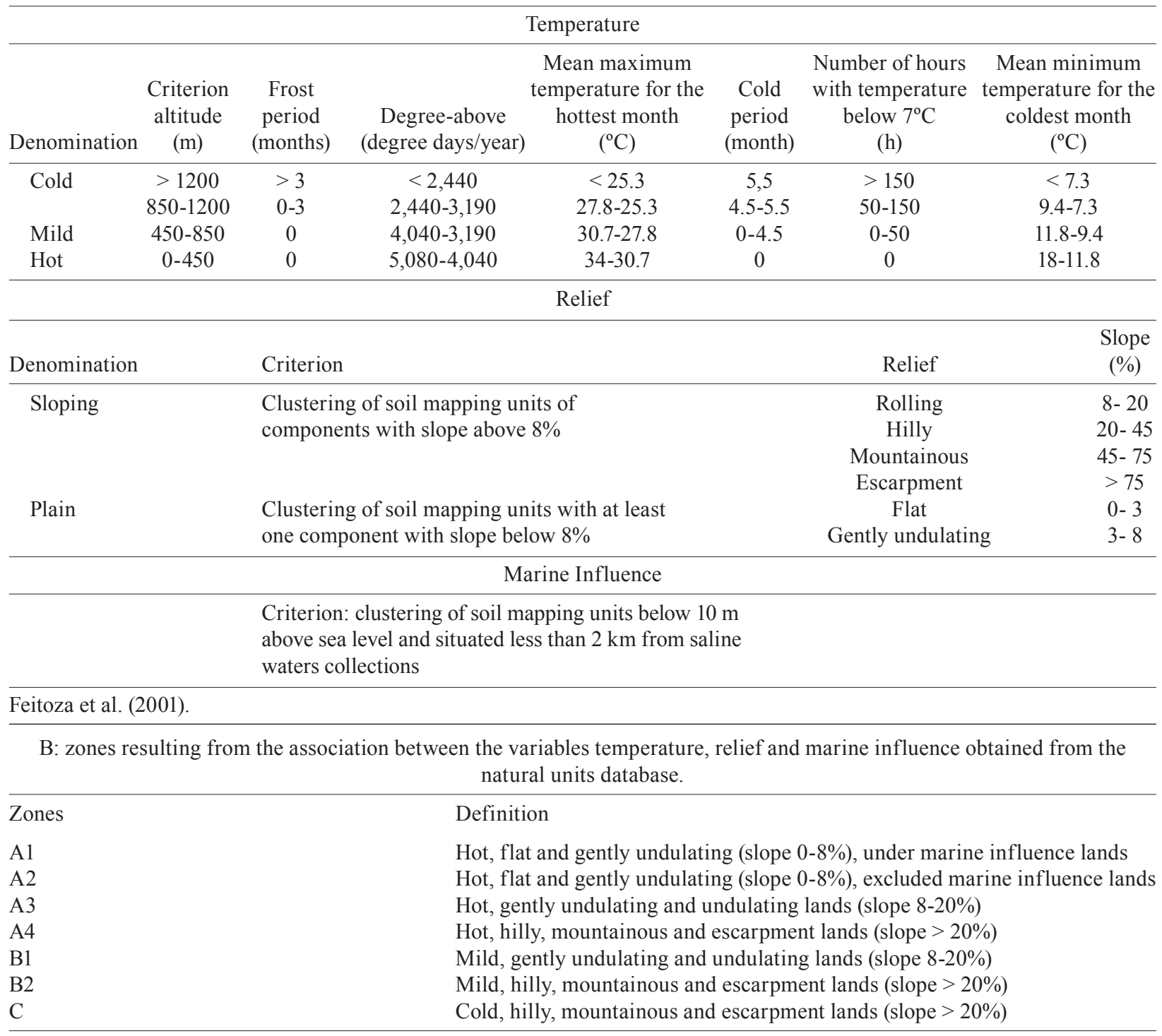




\section{RESULTS}

The 297 sampling localities were distributed evenly throughout all the geoclimatic zones of the state (Fig. 1). In all, 14,663 anophelines were collected belonging to 22 species (Table III). Eighty-one malaria foci were recorded from 1985-2005, divided among 19 municipalities. Significant, positive associations were found between malaria foci and the presence of environmental variables characterizing the following geoclimatic zones: A1 $\left(\chi^{2}=16.979 ; \mathrm{p}=0.000\right)$; A2 $\left(\chi^{2}=30.403\right.$; $\mathrm{p}=0.000)$ and A3 $\left(\chi^{2}=18.275 ; \mathrm{p}=0.000\right)$. Zones B2 $\left(\chi^{2}=33.533 ; \mathrm{p}=0.000\right)$ and $\mathrm{C}\left(\chi^{2}=8.352 ; \mathrm{p}=0.004\right)$ presented significant negative associations, indicating areas unfavourable for malaria transmission. Based on the geoclimatic characteristics identified for malaria foci, a map was prepared of the areas considered at risk for transmission of the disease (Fig. 2).

Areas characterized as being at risk for the transmission of malaria presented significant positive associations with the presence of An. darlingi $\left(\chi^{2}=83.732\right.$; $\mathrm{p}=0.000)$, Anopheles aquasalis $\left(\chi^{2}=17.943 ; \mathrm{p}=0.000\right)$, Anopheles albitarsis s.1. $\left(\chi^{2}=11.427 ; \mathrm{p}=0.001\right)$, Anopheles triannulatus s.1. $\left(\chi^{2}=6.504 ; \mathrm{p}=0.011\right)$ and Anopheles galvaoi $\left(\chi^{2}=5.396 ; \mathrm{p}=0.020\right)$. Significant negative associations were found for Anopheles lutzi $\left(\chi^{2}=\right.$ 32.470; $\mathrm{p}=0.000)$ and Anopheles oswaldoi s.1. $\left(\chi^{2}=9.630\right.$; $\mathrm{p}=0.002)$. Anopheles strodei $\left(\chi^{2}=3.370 ; \mathrm{p}=0.066\right)$, Anopheles evansae $\left(\chi^{2}=1.106 ; \mathrm{p}=0.293\right)$ and Anopheles argyritarsis $\left(\chi^{2}=0.517 ; \mathrm{p}=0.472\right)$ did not present significant associations with malaria distribution.

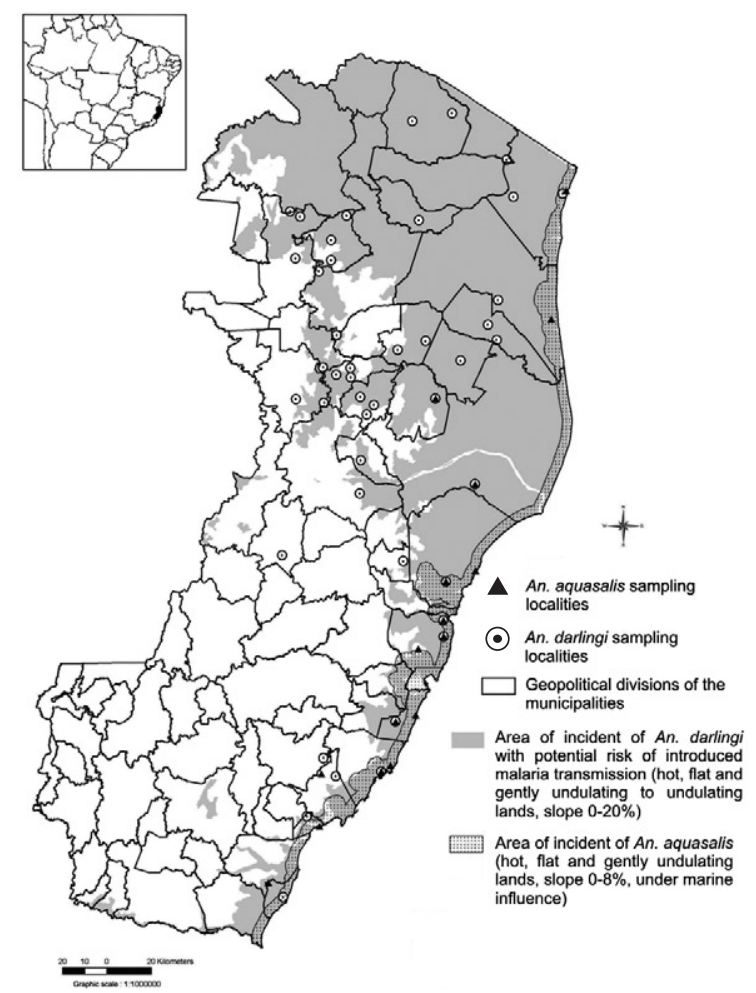

Fig. 2: distribution of Anopheles darlingi and Anopheles aquasalis and areas at risk for malaria transmission in the state of Espírito Santo, Brazil.
Based on multivariate analysis using binary logistic regression, the associations between the occurrence of An. darlingi $(\mathrm{p}=0.0000)$ and An. aquasalis $(\mathrm{p}=0.0024)$ and the areas at risk for transmission of malaria were significant. A significant correlation between malaria foci and An. darlingi occurrence was found in Zones A1 $\left(\chi^{2}=7.870 ; p=0.005\right)$, A2 $\left(\chi^{2}=18.980 ; p=0.000\right)$ and A3 $\left(\chi^{2}=35.998 ; \mathrm{p}=0.000\right)$. On the other hand, a negative association was noted between the presence of this species and Zones B2 $\left(\chi^{2}=32.018 ; \mathrm{p}=0.000\right)$ and $\mathrm{C}\left(\chi^{2}=5.852 ; \mathrm{p}=0.016\right)$ (Table IIB). The geoclimatic characteristics of An. aquasalis were present only in Zone A1 $\left(\chi^{2}=105.087 ; p=0.000\right)$. It was associated with brackish water in ES and is similar to other studies (FUNASA 2004) (Fig. 2).

\section{DISCUSSION}

Previous studies in ES found 17 of the 22 anopheline species identified in the present study (Table III) (Coutinho 1947, Andrade \& Brandão 1957, Ferreira 1964).

Hot, low-lying or gently undulating to undulating relief $(0-20 \%$ slope $)$ were characteristics for the potential risk of introduced malaria, which could lead to autochthonous malaria in ES (Zones A1, A2 and A3). Mountainous areas with moderate or cool temperatures (Zones B2 and C) may be considered as being protected against

\section{TABLE III}

Total number collected and percent of different Anopheles species in the state of Espírito Santo, Brazil, 1997-2005

\begin{tabular}{|c|c|c|}
\hline Species & Absolute freq. & $\%$ \\
\hline Anopheles evansae ${ }^{a}$ & 3,470 & 23.66 \\
\hline Anopheles strodei ${ }^{a}$ & 3,347 & 22.83 \\
\hline Anopheles albitarsis s.1. ${ }^{a}$ & 2,601 & 17.74 \\
\hline Anopheles argyritarsis ${ }^{a}$ & 1,851 & 12.62 \\
\hline Anopheles lutzi $i^{a}$ & 999 & 6.81 \\
\hline Anopheles galvaoi ${ }^{a}$ & 605 & 4.13 \\
\hline Anopheles darlingi $i^{a}$ & 503 & 3.43 \\
\hline Anopheles triannulatus s.1. ${ }^{a}$ & 425 & 2.90 \\
\hline Anopheles aquasalis ${ }^{a}$ & 228 & 1.55 \\
\hline Anopheles oswaldoi s.l. $^{a}$ & 178 & 1.21 \\
\hline Anopheles minor ${ }^{a}$ & 152 & 1.04 \\
\hline Anopheles nunestovari & 120 & 0.82 \\
\hline Anopheles lanei ${ }^{a}$ & 33 & 0.23 \\
\hline Anopheles sp. & 33 & 0.23 \\
\hline Anopheles parvus ${ }^{a}$ & 31 & 0.21 \\
\hline Anopheles cruzii ${ }^{a}$ & 28 & 0.19 \\
\hline Anopheles tibiamaculatus & 19 & 0.13 \\
\hline Anopheles costai & 11 & 0.08 \\
\hline Anopheles benarrochi & 10 & 0.07 \\
\hline Anopheles bellator ${ }^{a}$ & 9 & 0.06 \\
\hline Anopheles maculipes ${ }^{a}$ & 5 & 0.03 \\
\hline Anopheles intermedius ${ }^{a}$ & 3 & 0.02 \\
\hline Anopheles gilesi $^{a}$ & 2 & 0.01 \\
\hline Total & 14,663 & 100 \\
\hline
\end{tabular}

$a$ anopheline species identified in the present study that were found previously in state of Espírito Santo by Coutinho (1947), Andrade and Brandão (1957) and Ferreira (1964). 
the risk of introduced malaria transmission since the suspected vector for autochthonous malaria in mountainous regions, An. cruzii, has been collected almost exclusively in the forest canopy after sunset (Rodrigues 2005). This result explains the occurrence of isolated human cases of autochthonous malaria, probably originated from simians. An. cruzii behaviour seems to be different from that observed in other states of Southeast and South Brazilian Regions, where Kerteszia has been occurring frequently at ground level (Deane 1986, Ueno et al. 2007).

All of the evidence incriminates An. darlingi and $A n$. aquasalis as vectors of introduced malaria in ES. An. darlingi occurred in hot, flat to undulating areas in the littoral and the interior regions of the state (Zones A1, A2 and A3), while An. aquasalis was restricted to hot, low-lying areas under marine influence (Zone A1).

The results of the present study support the data in the scientific literature on this topic. According to Forattini (2002), An. darlingi is the principal South American vector of human malaria. Man-made alterations to the environment appear to influence the abundance of this species. The substitution of natural vegetation by plantations, pastures and other activities may create conditions favourable to its development. An. aquasalis is considered an important vector at high density, as commonly occurs in coastal areas during the rainy season (Forattini 1962, 2002). Moreover, a relationship has been demonstrated between vectors and specific ecoregions (RubioPalis \& Zimmerman 1997).

The results did not demonstrate any association between the presence of An. lutzi and An. oswaldoi s.l. and the occurrence of malaria foci in ES, since these species predominated in areas considered to be free from the risk of transmission. Considering the abundance of $A n$. strodei, An. evansae and An. argyritarsis in most of the localities studied, there is no indication that these species are important in malaria transmission.

GEOBASES and GISUNES were found to be efficient tools for discrimination of malaria risk areas in ES, demonstrating the influence of geoclimatic factors on vector distribution. Such association allows for predicting the occurrence of possible foci in indene areas.

Although the analysis did not emphasize the geopolitical divisions of the municipalities, it was considered relevant to show these in the maps in order to provide the municipal administrations with scientific bases for the identification of risk areas for malaria transmission, leading to the adoption of preventative and control measures against the disease.

\section{ACKNOWLEDGEMENTS}

To the technicians of the Entomology's Nucleus of Secretaryship of Health of State of Espírito Santo, to Bruce Alexander, for translating the manuscript into English, and to Ricardo Lourenço-de-Oliveira, for critical revision of the manuscript and valuable comments.

\section{REFERENCES}

Andrade RM, Brandão H 1957. Contribuição para o conhecimento da fauna de anofelinos do estado do Espírito Santo: área de distribuição e incidência das espécies por cidades, vilas e povoados. Rev Bras Malariol Doenças Trop 9: 391-403.
Atanaka-Santos M, Souza-Santos R, Czeresnia D 2007. Spatial analysis for stratification of priority malaria control areas, Mato Grosso State, Brazil. Cad Saude Publica 23: 1099-1112.

Consoli RAGB, Lourenço-de-Oliveira R 1994. Principais mosquitos de importância sanitária no Brasil, Fiocruz, Rio de Janeiro, $255 \mathrm{pp}$.

Coutinho JO 1947. Contribuição para o estudo da distribuição geográfica dos anofelinos do Brasil, MSc Thesis, Faculdade de Medicina da Universidade de São Paulo, São Paulo, 117 pp.

Deane LM 1986. Malaria vectors in Brazil. Mem Inst Oswaldo Cruz 81 (Suppl. II): 5-14.

Falqueto A, Stocking M, Fraga P, Resende M, Castro L, Borel R 2001. Information for specific use: case studies. In LR Feitoza, M Stocking, M Resende, Natural resources information systems for rural development: approaches for Espirito Santo State, Brazil, Incaper, Vitória, p. 97-107.

Feitoza HN 2006. Desenvolvimento de um sistema geográfico de informações para as unidades naturais do estado do Espírito Santo integrado ao GEOBASES, Incaper/Fundagres, Vitória, 7 pp, unpublished observations.

Feitoza LR, Stocking M, Resende M 2001. Natural resources information systems for rural development: approaches for Espirito Santo state, Brazil, Incaper, Vitória, 223 pp.

Ferreira E 1964. Distribuição geográfica dos anofelinos no Brasil e sua relação com o estado atual da erradicação da malária. Rev Bras Malariol Doenças Trop 16: 329-338.

Forattini OP 1962. Entomologia Médica, Vol. I, Faculdade de Higiene e Saúde Pública, São Paulo, 662 pp.

Forattini OP 2002. Culicidologia médica: identificação, biologia e epidemiologia, Vol. II, Edusp, São Paulo, 864 pp.

Forattini OP 2004. Ecologia, epidemiologia e sociedade, 2nd ed., Artes Médicas, São Paulo, 710 pp.

FUNASA - Fundação Nacional de Saúde 2001. Manual de terapêutica de malária, Ministério da Saúde, Brasília, 104 pp.

FUNASA - Fundação Nacional de Saúde 2004. Coordenação regional do estado do Espírito Santo. Malária: dados epidemiológicos, FUNASA, Vitória, $10 \mathrm{pp}$.

IPEMA - Instituto de Pesquisa da Mata Atlântica 2004. Conservação da Mata Atlântica no estado do Espírito Santo: cobertura florestal, unidades de conservação e fauna ameaçada, IPEMA, Vitória, $112 \mathrm{pp}$.

Margonari C, Freitas CR, Ribeiro RC, Moura ACM, Timbó M, Gripp AH, Pessanha JE, Dias ES 2006. Epidemiology of visceral leishmaniasis through spatial analysis, in Belo Horizonte municipality, state of Minas Gerais, Brazil. Mem Inst Oswaldo Cruz 101: 31-38.

Marques AC 1986. Migrations and the dissemination of malaria in Brazil. Mem Inst Oswaldo Cruz 81 (Suppl. II): 17-30.

MS - Ministério da Saúde 2003. Secretaria de Vigilância em Saúde. Programa Nacional de Prevenção e Controle da Malária PNCM, Ministério da Saúde, Brasília, 131 pp.

MS - Ministério da Saúde 2007. Fundação Nacional de Saúde. Vigilância em Saúde. Situação epidemiológica da malária no Brasil 2007, MS, Brasília, 6 pp.

Neves DP 2003. Parasitologia dinâmica, Atheneu, São Paulo, p. 155176, 403-404.

Neves DP, Melo AL, Genaro O, Linardi PM 2000. Parasitologia humana, Atheneu, São Paulo, 528 pp. 
Rey L 2001. Parasitologia, Guanabara Koogan, Rio de Janeiro, 856 pp.

Rezende HR, Cerutti Júnior CC, Santos CB 2005. Aspectos atuais da distribuição geográfica de Anopheles (Kerteszia) cruzii Dyar \& Knab, 1908 no estado do Espírito Santo, Brasil. Entomol Vect 12: $123-126$

Rodrigues AF, Escobar AL, Souza-Santos R 2008. Spatial analysis and determination of malaria control areas in the State of Rondônia. Rev Soc Bras Med Trop 41: 55-64.

Rodrigues SWF 2005. Características ecológicas da fauna de anofelinos (Díptera: Culicidae) em área de transmissão de malária autóctone, na Região Serrana do estado do Espírito Santo, MSc Thesis, Universidade Federal do Espírito Santo, Vitória, 51 pp.

Rosa-Freitas MG, Tsouris P, Peterson AT, Honório NA, Barros FSM, Aguiar DB, Gurgel HC, Arruda ME, Vasconcelos SD, LuitgardsMoura JF 2007. An ecoregional classification for the state of Roraima, Brazil: the importance of landscape in malaria biology. Mem Inst Oswaldo Cruz 102: 349-357.
Rubio-Palis Y, Zimmerman RH 1997. Ecoregional classification of malaria vectors in the Neotropics. J Med Entomol 34: 499-510.

SEAMA - Secretaria de Estado de Meio Ambiente e Recursos Hídricos 2008. Atlas de Ecossistemas do Estado do Espirito Santo, UFV, Vitória, 504 pp.

Ueno HM, Forattini OP, Kakitani I 2007. Distribuição vertical e sazonal de Anopheles (Kerteszia) em Ilha Comprida, SP. Rev Saude Publica 41: 269-275.

Vasconcelos CH, Novo EMLM, Donalisio MR 2006. Uso do sensoriamento remoto para estudar a influência de alterações ambientais na distribuição da malária na Amazônia brasileira. Cad Saude Publica 22: 517-526.

WHO - Word Health Organization 2008. World Malaria Report 2008, WHO, Geneva, 190 pp.

Zeilhofer P, Santos ES, Ribeiro ALM, Miyazaki RD, Atanaka-Santos M 2007. Habitat suitability mapping of Anopheles darlingii in the surroundings of the Manso hydropower plant reservoir, Mato Grosso Central, Brazil. Int J Health Geogr 6: 1-24. 